UDK 582.728.4:630*27(497.6 Sarajevo)

\title{
PRESENCE OF MISTLETOE (Viscum album L.) ON URBAN TREES OF SARAJEVO
}

\section{Prisustvo imele (Viscum album L.) na drveću u Sarajevu}

\author{
Tarik Treštić ${ }^{1}$, Osman Mujezinović ${ }^{1}$, Azra Čabaravdić ${ }^{1}$ and Tatjana Veselinović ${ }^{2}$
}

\begin{abstract}
This paper has identified the presence of mistletoe (Viscum album ssp. album) on the trees in the urban part of Sarajevo. The mistletoe is a semi-parasitic flowering plant, which grows on a large number of hosts. In general, mistletoes are specialized species, which parasite only on particular trees and shrub species. They cause the dying of different forest species and the decorative trees. As for the forests in Bosnia and Herzegovina, the most important is mistletoe on fir ( $V$. album ssp. abietis), while in terms of fruit trees and trees in urban areas, the mistletoe particularly grow on deciduous species ( $V$. album ssp. album).

Researches for the purpose of this paper were effectuated in 2008 in the area of municipality Novo Sarajevo. Mistletoe ( $V$. album ssp. album) has been identified on 37 infected trees, or on 12 species belonging to 5 families and 7 genera. The analysis of number of shrubs in the crowns of infected trees identified the intensity of the infection by this semi-parasitic species.

The mistletoe is a primary harmful agent on urban trees and shrubs. Larger number of mistletoe shrubs exhausts the infected host, and it makes the host suitable for the attack by other secondary harmful insects and pathogens. Thus, it is recommended to remove the mistletoe shrubs, even in early stage of development of disease, while the trees are still infected (1-2 shrubs) to a lesser degree.
\end{abstract}

Key words: mistletoe, hosts of semi-parasitic species, intensity of infection, health condition.

\section{INTRODUCTION - Uvod}

Viscum album L., the mistletoe is semi-parasitic evergreen plant which takes from the host the water and mineral substances. Leaves of mistletoe are distributed opposite to each other, bare, skin-like and of yellow-green color, reversed egg-shape to elongated form. Branches are apparently dichotomically developed forming the

\footnotetext{
${ }^{1}$ Faculty of forestry, University of Sarajevo

${ }^{2}$ Master student, Faculty of forestry, University of Sarajevo
} 
shrubs with diameter of up to $1 \mathrm{~m}$. Branches are of green-brown color, internoded and easily breaking on joints.

Mistletoe is dioecious plant. Pollination of its flower is conducted by insects. It is flowering in spring, from February to May. After the pollination, the twigs with male flowers dry-of and fell down. The fruit is a berry with green pericarp, which upon ripen becomes brighter. It contains a sticky substance - viscin. Fruits ripen by the end of autumn or by the beginning of winter and it contain one seed. Dissemination of seeds to larger distances is conducted by birds which eat the mistletoe berries, while the local dispersion is conducted by self-dissemination. Seeds germinate at spring forming the appressorium from which the primary sinker penetrates through the bark all the way to the tree core. Next year from this sinker are developed lateral fibrous growth - rhizoids with secondary sinker which reach the tree core. Sinkers absorb water and mineral substances from the xylem of the host. With the development of the surface part of the mistletoe (the shrub) also grow in length the rhizoids from which grow new sinkers which ingrown into the youngest annual ring of the tree. From the tip parts of these rhizoids are differentiated the adventive buds in such way creating the new mistletoe shrubs, which represents the vegetative way of reproduction of the mistletoe.

Areal of the species $V$. album is limited on the North by southern Scandinavia and on West by central and southern England. It spreads to the South up to the southwest of Africa and to East across south-west and central Asia, all the way to Manchuria and Japan (HEGI, 1981). According to BARNEY ET AL. (1998), of three subspecies of mistletoe, V. album ssp. album is the less specialized. Of its wide presence can speak the data that it was registered even at 452 taxa (HAWSKWORTH ET AL., 1993). By researches conducted in Spain the mistletoe was registered on 34 taxonomic categories (LOPEZ - SAEZ, 1994), while in Switzerland it occurred on plants from 17 genera (HOFSTETTER, 1988). In the area of Central Europe hosts of this species have origin from 36 genera (HEGI, 1981). According to IDŽOJTIĆ (2003), hosts of mistletoe in the area of Croatia are the plants from 45 taxa.

\section{MATERIAL AND METHODS - Materijal i metode}

Researches that are the subject of this paper were conducted in the area of city of Sarajevo, municipality Novo Sarajevo, at 8 localities: Kovačići, Vraca, Grbavica, Trg Heroja, Hrasno, Čengić Vila, Dolac Malta and Pofalići. This area is characterized by moderate continental climate created as the result of impacts of central-European climate from north, Mediterranean climate from the south and due to diverse relief. Its basic characteristics are warm summers and relatively cold winters.

The goal of the research was to identify the presence of $V$. album ssp. album on trees of city of Sarajevo. Data collection was conducted in the period February May 2008. On that occasion were examined all trees of city vegetation and for those where was registered the presence of mistletoe was identified the following: tree 
species, location of the tree and number of shrubs for the purpose of designation of the intensity of infection.

Designation of the intensity of infection was conducted according to the method of HAWSKWORTH (2005). According to this method the crown of infected trees is divided into thirds. For every third is designated the index of infection (index 0 - no mistletoe shrubs; index 1 - if the mistletoe shrubs are present on less than half of the total number of branches and index 2 - if the presence of the shrubs in observed third of the crown was recorded on more than half of the total number of branches). By summing up of the individual indices for all thirds was obtained the total infection index. The tree is characterized as low infected if the value of the index is 1 or 2 . Medium infected are trees with index 3 or 4 while to the category of severely infected trees belong tress with index 5 or 6 .

Based on the collected information were established basic statistical indicators (number/abundance and mode) and presented the structure and percentual distribution of trees according to the intensity of infection.

\section{Results - Rezultati}

According to the above defined methodology of the research, there was conducted the assessment of parameters on 37 trees infected by mistletoe. In Table 1 was given the presentation of tree species where the shrubs of $V$. album ssp. album were registered. Locations of infected trees are presented in Table 2, while the intensity of infection of trees is given in Table 3.

Table 1. Taxonomic belonging of trees infected by mistletoe

Tabela 1. Taksonomska pripadnost imelom araženih stabala

\begin{tabular}{|c|c|c|c|c|}
\hline \multirow[b]{2}{*}{ Family } & \multirow[b]{2}{*}{ Genus } & \multicolumn{2}{|c|}{ Tree species } & \multirow{2}{*}{$\begin{array}{c}\text { Number of } \\
\text { infected } \\
\text { trees }\end{array}$} \\
\hline & & Latin name & English name & \\
\hline Aceraceae & Acer & Acer platanoides & Norway maple & 4 \\
\hline Aceraceae & Acer & Acer pseudoplatanus & Sycamore maple & 4 \\
\hline Aceraceae & Acer & Acer dasycarpum & Silver maple & 2 \\
\hline Leguminossae & Robinia & Robinia pseudoacacia & Black locust & 3 \\
\hline Rosaceae & Malus & Malus sylvestris & Common apple & 1 \\
\hline Rosaceae & Sorbus & Sorbus aucuparia & European mountain ash & 3 \\
\hline Salicaceae & Populus & Populus alba & Silver-leaf poplar & 2 \\
\hline Salicaceae & Populus & Populus nigra & Black poplar & 5 \\
\hline Salicaceae & Salix & Salix chrysocoma & Golden willow & 2 \\
\hline Tiliaceae & Tilia & Tilia platyphyllos & Large-leaved lime & 3 \\
\hline Tiliaceae & Tilia & Tilia cordata & Small-leaved lime & 1 \\
\hline Tiliaceae & Tilia & Tilia tomentosa & Silver lime & 7 \\
\hline
\end{tabular}


Table 2. Presentation of the location of trees infected by mistletoe

Tabela 2. Prikaz lokacije imelom zaraženih stabala

\begin{tabular}{|c|c|}
\hline Tree species & Location \\
\hline Acer platanoides & \multirow{2}{*}{ Socijalno; Hypo Group bank; Northwards } \\
\hline Acer platanoides & \\
\hline Acer platanoides & Grbavica; $40 \mathrm{~m}$ from Yauth centre \\
\hline Acer platanoides & Grbavica; $20 \mathrm{~m}$ from Yauth centre \\
\hline Acer pseudoplatanus & \multirow{3}{*}{$\begin{array}{l}\text { Street Franje Račkog 3; National museum of Bosnia and Herzegovina } \\
\text { North side }\end{array}$} \\
\hline Acer pseudoplatanus & \\
\hline Acer pseudoplatanus & \\
\hline Acer pseudoplatanus & National museum of Bosnia and Herzegovina; East side \\
\hline Acer dasycarpum & Street Grbavička 32; Southwards to baker s shop "Grbavica 2" \\
\hline Acer dasycarpum & Left confluent of Miljacka river; courtyard of the mosque \\
\hline Robinia pseudoacacia & National museum of Bosnia and Herzegovina; East side \\
\hline Robinia pseudoacacia & National museum of Bosnia and Herzegovina; South side \\
\hline Robinia pseudoacacia & Courtyard of the Historical museum of Bosnia and Herzegovina \\
\hline Malus sylvestris & Street Travnička 1; Embassy of Hungary \\
\hline Sorbus aucuparia & \multirow{2}{*}{ Courtyard of the Franciscan Student Centre - Sarajevo } \\
\hline Sorbus aucuparia & \\
\hline Sorbus aucuparia & Street Kemala Kapetanovića 28; Left confluent of Miljacka river \\
\hline Populus alba & Street Kemala Kapetanovića 37; Left confluent of Miljacka river \\
\hline Populus alba & Street Kemala Kapetanovića 35; Left confluent of Miljacka river \\
\hline Populus nigra & Street Kolodvorska 12c; Energoinvest; Southwards $40 \mathrm{~m}$ \\
\hline Populus nigra & Street Kolodvorska 12c; Energoinvest; Southwards $50 \mathrm{~m}$ \\
\hline Populus nigra & \multirow{3}{*}{ Socijalno; Southwards from Emergency building } \\
\hline Populus nigra & \\
\hline Populus nigra & \\
\hline Salix chrysocoma & \multirow{2}{*}{ Street Kemala Kapetanovića 41; Left confluent of Miljacka river } \\
\hline Salix chrysocoma & \\
\hline Tilia platyphyllos & Novi Robot; car parking \\
\hline Tilia platyphyllos & \multirow{2}{*}{ Grbavica; behind “Agronom”; Driving school 92} \\
\hline Tilia platyphyllos & \\
\hline Tilia cordata & Street Šaćira Sikirića 6; Embassy of Hungary \\
\hline Tilia tomentosa & \multirow{4}{*}{ National museum of Bosnia and Herzegovina; North side } \\
\hline Tilia tomentosa & \\
\hline Tilia tomentosa & \\
\hline Tilia tomentosa & \\
\hline Tilia tomentosa & Street Kemala Kapetanovića 21 \\
\hline Tilia tomentosa & Street Kemala Kapetanovića 23 \\
\hline Tilia tomentosa & Grbavica, Yauth centre, sports field \\
\hline
\end{tabular}


Table 3 Intensity of infection of trees (according to belonging genus)

Tabela 3. Intenzitet zaraženosti drveća (prema pripadajaćem rodu)

\begin{tabular}{|c|c|c|c|c|c|c|c|c|c|}
\hline \multirow{2}{*}{ Genus } & \multirow{2}{*}{$\begin{array}{l}\text { Number } \\
\text { of shrubs }\end{array}$} & \multicolumn{6}{|c|}{ Intensity of infection } & \multicolumn{2}{|c|}{ Infected trees } \\
\hline & & Low & $\%$ & Middle & $\%$ & Severe & $\%$ & Total & $\%$ \\
\hline Acer & 152 & 7 & 70,0 & 2 & 20,0 & 1 & 10,0 & 10 & 100 \\
\hline Malus & 7 & - & - & 1 & 100 & - & - & 1 & 100 \\
\hline Populus & 217 & 3 & 42,9 & - & - & 4 & 57,1 & 7 & 100 \\
\hline Robinia & 7 & 3 & 100 & - & - & - & - & 3 & 100 \\
\hline Salix & 86 & - & - & - & - & 2 & 100 & 2 & 100 \\
\hline Sorbus & 22 & 3 & 100 & - & - & - & - & 3 & 100 \\
\hline Tilia & 139 & 6 & 54,5 & 5 & 45,5 & - & - & 11 & 100 \\
\hline
\end{tabular}

\section{DISCUSSION - Diskusija}

The conducted researches had for a goal to identify the presence of $V$. album ssp. album on trees in the city of Sarajevo, and the intensity of infection of those trees. Upon the examination of city vegetation in the researched area was recorded the presence of mistletoe on 37 trees in total.

According to the results of the research (Table 1) the mistletoe were the most present on Silver lime (seven trees). In five cases it was registered on Black poplar, while on Sycamore maple, Norway maple and Black locust it was registered in four trees of each species. Three trees for each of species of Silver maple, European mountain ash and Large-leaved lime were identified as hosts of this species of mistletoe, while on Silver-leaf poplar and Golden willow it was registered on two trees of each species. The lowest presence of mistletoe was identified on Common apple and Small-leaved lime (one tree of each). However, these data cannot be used for the purpose of assessment of endangerment of particular tree species due to mistletoe. Namely, in the focus of research were only trees with mistletoe shrubs and not those of the same tree species that are healthy. Nevertheless, one could notice that the mistletoe prefers trees the crowns of which build the upper layer of urban vegetation in Sarajevo. This was conditioned by the need of mistletoe for light in order to conduct the process of photosynthesis (semi-parasitic plant). Therefore the results of these researches are in accordance with the results of other researchers (IDŽOJTIĆ, 2003; IDŽOJTIĆ AND KOGELNIK, 2003).

Detailed locations of infected trees (Table 2) in this paper enable the monitoring of the development and further spreading of semi-parasitic plants on this locality, and undertaking the protection measures on particular trees of city vegetation. Keeping of severely infected trees in Sarajevo points to the lack of timely intervention with a goal to remove the semi-parasitic plants. In such way is reduced the vitality and life cycle of the tree. Due to the lack of reaction particular objects in Sarajevo are lost and total reconstruction will be the only possible solution. Removal of individual, 
severely infected trees of poplar in the area of municipality Novo Sarajevo was already recorded in past years. In certain time we can expect the removal of the whole maple tree-line walk on the access road to Vogošća the dying of which was directly initiated by mistletoe (TREŠTIĆ ET AL., 2008).

Results of the conducted researches confirm the existence of differences in the intensity of infection of particular species of hosts (Table 3). On 37 infected trees was identified in total 623 mistletoe shrubs (in average 16.8 shrubs per tree). This is a significant potential of pathogen both, regarding further spreading as well as regarding the endangering of the vitality of infected trees. The largest number of shrubs was identified on trees of Black poplar and Silver-leaf poplar (109 and 108 shrubs; in average 54.5 and 27 shrubs per tree). Severely infected also are trees of Golden willow (in average 43 shrubs per tree). Then follow maples with 15.2 shrubs per tree and limes with 12.6 shrubs per tree. The lowest infection was identified on Black locust (2.3 shrubs per tree). Mistletoe was not identified on species of genera Aesculus, Prunus, Platanus and Fraxinus which are also mentioned by other authors as sporadic hosts of the mistletoe (IDŽOJTIĆ, 2003; IDŽOJTIĆ AND KOGELNIK, 2003).

On severely infected trees mistletoes causes non-economic water consumption which results in dehydration of trees and gradual dying. The taking away of water and mineral substances is how the mistletoe is primarily weakening the vitality of the host. As an indicator of negative effects of mistletoe on infected trees can serve a difference in biomass of the Silver fir needles (UsČUPLIĆ ET AL., 2008) or the difference in diameter of the branches before and after the point of infection (unpublished results of the research on mistletoe on oak and pines). Trees more severely infected by mistletoe are favorable for attacks of secondary biotic and biotic harmful agents. To such primary harmful impact of mistletoe point also the other author in their papers (MUJEZINOVIĆ, 2007; TREŠTIĆ ET AL., 2006).

\section{REFERENCES - Literatura}

Barney, C. W., HaWskworth, F. G., Geils, B.W. (1998): Hosts of Viscum album. Eur. J. For. Path. 28: 187-208.

Hawskworth, F. G., PundiR, Y. P. S., Shaw, C. G., Geils, B. W. (1993): The host range of Dendrophthoefalcata (L. f.) Ettingsh. (Loranthaceae). Indian J. For. 16: 263-281.

HeGI, G. (1981): Illustrierte Flora von Mitteleuropa, Band III, Teil 1. Verlag Paul Parey, Berlin, Hamburg, 504 pp.

Hofstetter, M. (1988): Ober die Verbreitung der Mistel in der Schweiz. Schweiz. Z. Forstwes. 139 (2): 97-127.

IDŽOJTIĆ, M. (2003): Domaćini i rasprostranjenost bjelogorične imele (Viscum album L. ssp. album) U Hrvatskoj. Šumarski list br. 9-10, CXXVII (2003), 439-447. 
IDŽOJTIĆ, M. AND KOGELNIK, M. (2003): Hosts of mistletoes in Croatia and Slovenia. In: Abstract book of the International Symposium on Vegetation in SE Europe, Otočec, Slovenia, May 29-31, 2003, 26 p.

LOPEZ - SAEZ, J. A. (1994): Note on some taxonomic considerations on the subspecies of Viscum album in the Iberian Peninsula as a function of the hosts. Investigacion Agraria, Sistemas y Recursos Forestales 3(1): 69-73.

MUJEZINOVIĆ, O. (2007): Uticaj imele (Viscum album L.) na prirast jele (Abies alba M.) i ulančavanje drugih štetnih biotičkih agenasa. Magistarski rad. Šumarski fakultet Univerziteta u Sarajevu.

TREŠtIĆ, T., DAUTBAŠIĆ, M. I MUJEZINOVIĆ O. (2006): Uticaj hrastove imele (Loranthus europaeus Jacq.) na stabilnost sastojina hrasta kitnjaka. Radovi Šumarskog fakulteta Univerziteta u Sarajevu, No. 1, 2006 (87 - 93).

TREŠTIĆ, T., DAUTBAŠIĆ, M. I MuJeZINOVIĆ O. (2008): Zdravstveno stanje zelenila na području Vogošće. V Simpozij zaštite bilja u Bosni i Hercegovini, Sarajevo.

UsČuplić, M., TREŠTIĆ, T., DAUTBAŠIĆ, M. I MUJEZINOVIĆ, O. (2008): Utjecaj imele na biomasu iglica obične jele. Radovi Šumarskog instituta, Jastrebarsko, 43 (1): $31-37$.

\section{SAŽETAK}

U ovom radu utvrđivano je prisustvo bijele imele (Viscum album ssp. album) na drveću grada Sarajeva. Bijela imela je poluparazitska cvjetnica koja se javlja na velikom broju domaćina. Ove biljke su uzročnici sušenja raznih vrsta šumskog i ukrasnog drveća. U šumarstvu Bosne i Hercegovine najznačajnija je imela na jeli ( $V$. album ssp. abietis) dok je za voće i drveće gradskog zelenila od posebnog značaja imela na lišćarima ( $V$. album ssp. album).

Istraživanja, koja su predmet ovog rada, provedena su na području grada Sarajeva, općina Novo Sarajevo, na 8 lokaliteta: Kovačići, Vraca, Grbavica, Trg Heroja, Hrasno, Čengić Vila, Dolac Malta i Pofalići. Cilj istraživanja bio je utvrđivanje prisustva $V$. album ssp. album na drveću grada Sarajeva. Prikupljanje podataka obavljeno je u periodu februar - maj 2008. godine. Pri tome su pregledana sva stabla gradskog zelenila a za ona na kojima je zabilježeno prisustvo imele utvrđeno je sljedeće: vrsta drveta, lokacija stabla i broj grmova radi određivanja intenziteta zaraženosti. Određivanje intenziteta zaraženosti vršeno je prema metodi HAWSKWORTHA. Prema ovoj metodi krošnja zaraženih stabala se podijeli na trećine. Svakoj trećini se odredi indeks zaraženosti (indeks 0 - nema grmova imele; indeks 1 ako su grmovi imele prisutni na manje od polovine ukupnog broja grana i indeks 2 ako je prisustvo žbunova u posmatranoj trećini krošnje zabilježeno na više od polovine ukupnog broja grana). Sumiranjem pojedinačnih indeksa za sve trećine dobija se ukupni indeks zaraženosti prema kojem se stablo karakteriše kao blago zaraženo, ako je veličina indeksa 1 ili 2.; srednje napadnuto, ako je indeks 3 ili 4; dok kategoriji jako zaraženih pripadaju stabla sa indeksom 5 ili 6 . 
Prema rezultatima istraživanja (tabela 1) imela je bila najprisutnija na bijeloj lipi (sedam stabala). U pet slučajeva registrovana je na crnoj topoli, dok je na gorskom javoru, javoru mliječu te bagremu zabilježena na po četiri stabla. Po tri stabla srebrenolisnog javora, jarebike i velelisne lipe utvrđeni su kao domaćini ove vrste imele, dok je na bijeloj topoli i žalosnoj vrbi bila na po dvije jedinke. Najmanje prisustvo imele utvrđeno je na jabuci i sitnolisnoj lipi (po jedno stablo).

Rezultati provedenih istraživanja potvrđuju postojanje razlika $\mathrm{u}$ intenzitetu zaraženosti pojedinih vrsta domaćina (tabela 3 ). Na 37 zaraženih stabala primjećeno je ukupno 623 grma imele (prosječno 16,8 grmova po stablu). Riječ je značajnom potencijalu patogena kako u pogledu daljenjeg širenja tako i u pogledu ugrožavanja vitalnosti zaraženih stabala. Najveći broj grmova konstatovan je na stablima bijele i crne topole (109 i 108 grmova; prosječno 54,5 i 27 grmova po stablu). Jako su zaražena i stabla žalosne vrbe (prosječno 43 grma po stablu). Slijede javorovi sa 15,2 grma po stablu i lipe sa 12,6 grmova po stablu. Najblaža zaraza konstatovana je na bagremu (2,3 grma po stablu). Imela nije primjećena na vrstama rodova Aesculus, Prunus, Platanus i Fraxinus koje i drugi autori navode kao njene sporadične domaćine (IDŽOJTIĆ, 2003; IDŽOJTIĆ I KOGELNIK, 2003).

Imela je primarni štetni agens na drveću i grmlju. Veći broj njenih grmova iscrpljuje napadnutog domaćina i čini ga podložnim napadu sekundarnih štetnih insekata i uzročnika bolesti. Zbog toga se sugeriše uklanjanje grmova imele još u ranoj fazi razvoja bolesti, dok su stabla neznatno zaražena (1-2 grma). 